\title{
Cirkulárna vizualizácia dát dochádzky za prácou na príklade obcí Bratislavského samosprávneho kraja
}

\author{
Vladimír BAČÍK, Dominika CHVOSTEKOVÁ
}

\section{Circular visualization of commuting data on the example of the Bratislava self-governing region communes}

Abstract: Circular visualization has recently become a kind of imaginary leader in the field of graphic visualization, mainly due to its attractive circular layout and the ability to display large amounts of data. In our paper, we focused only on a small subset of this group, namely the creation of chord diagrams that are useful in depicting the interrelationships between the observed regions. Commuting data represent an ideal example of such use, as we can clearly identify the source and target regions. In our paper, we used the communes of the Bratislava self-governing region as a model territory and data on daily commuting to work and schools from 2011. We used two basic tools to create these diagrams. Using Circos online application we created static chord diagrams, interactive diagrams were created using D3 library, which has integrated functions for creating such graphical outputs. It is a relatively frequently used graphic expression in the world, but very rarely in Slovakia and neighboring countries. In this paper we want to point only to the basic possibilities and limits of this attractive graphic form, which is very often used in the Internet for displaying various data.

Keywords: Circular visualization, Chord diagram, Commuting data, Circos, D3

\section{Úvod do problematiky dátovej vizualizácie}

Súčasná informačná spoločnost' je identifikovaná využivaním rôznorodých informačných služieb v online prostredí, ako aj generovaním obrovského množstva dát. Zdiel'anie týchto dát, či už v prostredí sociálnych sietí (fotografie, videá) alebo v špecifických dátových úložiskách, čelí v súčasnosti mnohým výzvam. Jednou z dôležitých oblastí zaoberajúcou sa efektívnou distribúciou týchto dát koncovým užívatel’om je oblast' dátovej vizualizácie. Existuje značný počet vizualizačných metód a techník, ktoré dokážeme aplikovat' na dáta rozličného charakteru. Ciel'om nášho príspevku je poukázat' na možnosti cirkulárnej vizualizácie dát so zameraním na podskupinu tzv. chord diagramov. Práve rôzne formy cirkulárnej vizualizácie sa v ostatnom období výrazne rozšírili pri tvorbe rozličných grafických výstupov či už v odborných vedeckých článkoch, ale aj v komerčných médiách, ktoré prezentujú aktuálne javy, udalosti v podobe variabilných infografík a prezentačných plagátov. Kým prejdeme k samotnej podstate nášho príspevku, a teda k predstaveniu samotného konceptu cirkulárnej vizualizácie, je dôležité uvedomit' si samotný význam dátovej vizualizácie a čo tento proces predstavuje.

Zmyslom vizualizácie je zobrazenie čísiel, resp. dát, z ktorých na základe ich vizuálneho zobrazenia vieme získat informáciu, ktorá je v inej podobe skrytá. Najjednoduchším príkladom môže byt' znázornenie časového radu vývoja počtu obyvatel'ov v l'ubovol'nej priestorovej jednotke. Pri klasickom tabul'kovom znázornení nemôžeme pozorovat' základný trend (nárast, pokles, stagnácia), ktorý je badatel'ný v ich grafickom vyjadrení. Základným faktom je skutočnost', že l'udský mozog spracováva ovel'a efektívnejšie informácie v ich vizuálnej podobe.

Vizualizácia dát umožňuje ciel’ovej skupine rýchlo získat' názor na dátový rozsah (Wang a kol. 2008). Rôznorodé techniky dátovej vizualizácie pomáhajú prezentovat' vel'ké množstvo

DOI: https://doi.org/10.33542/GC2020-1-01 
informácií v čo najefektívnejšej vizuálnej podobe (Kirk 2012). Samotný výstup umožňuje z komplikovaných dát vytvorit' obraz, v ktorom je na prvý pohl'ad viditel'né aj relatívne skryté (Ali a kol. 2016). Pri tvorbe vizualizácie je vel'mi dôležitý výber metódy, ktorá je vhodná pre dané údaje a ich znázornenie. Často sa stretávame s použitím nesprávneho typu grafu, čo výslednú interpretáciu devalvuje. Vizualizácia je správna, ak si po jej preštudovaní čitatel' položí otázku, týkajúcu sa predmetných dát, resp. možných variantov ich explanácie. Vizuálne zobrazené údaje sú l'ahšie pochopitel'né a analyzovatel'né. Pre decízorov je dôležitá aj samotná rýchlost' nájdenia vzorcov a porozumenie zložitým vzt’ahom medzi entitami, ktoré dané dáta prezentujú. Vizualizácia údajov tak môže byt' nápomocná pri identifikácii problémov a deficitov, pri výbere najlepšej stratégie fungovania produktu a firmy, pri prognózovaní objemu predaja a cien akcií, dolad'ovania riadenia projektov, optimalizácii dopravných tokov, atd'. (Bylinskii a kol. 2017). Existuje množstvo základných motívov pre využitie vizualizácie dát. Medzi tieto možno zaradit’aj (upravené podl'a Pursel 2005):

- Vysvetlenie údajov alebo uvedenie údajov do kontextu (zvýraznenie podstatných vecí)

- Identifikácia problémových oblastí (rôzne extrémne výkyvy, abnormality)

- Identifikácia časových, priestorových a objemových špecifík

- Zvýraznenie existujúcich väzieb medzi skúmanými entitami

- Zvýraznenie alebo ilustrovanie inak neviditel’ných údajov (napríklad izolovat' odlaahlé údaje, ktoré sa nachádzajú v údajoch).

Hybnou silou dátovej vizualizácie bol vývoj počítačovej technológie. Počítače umožnili spracovanie vel'kého množstva údajov vel'kou rýchlost’ou. Dnes sa vizualizácia údajov stala rýchlo sa rozvíjajúcou zmesou vedy a umenia a v súčasnosti je vizualizácia údajov mnohými vedeckými disciplínami považovaná za moderný ekvivalent vizuálnej komunikácie (Pursel 2015). Dátová vizualizácia výrazne zmenila pohl’ad na dáta a ich interpretáciu. V súčasnosti si s pojmom dátovej vizualizácie spájame prezentáciu zvyčajne dynamických, interaktívnych objektov, ktoré užívatel'sky prijatel'ným spôsobom komunikujú s klientom a sprostredkovávajú mu nejakú informáciu, ktorú chceme zdôraznit'. Počítače jednoznačne akcelerovali vývoj v tejto oblasti, avšak samotná problematika vizualizácie dát siaha do dávnej minulosti. Z historického pohl'adu je zaujímavá štúdia Friendly (2008), v ktorej autori poukázali na historické míl'niky vo využívaní štatistických, kartografických a grafických metód v oblasti dátovej vizualizácie. Za jedno z prelomových multivariačných diel dátovej vizualizácie je považovaná práca Charlesa Minarda z roku 1812, v ktorej zmapoval Napoleonovu inváziu do Ruska, pričom jeho grafický výstup kombinoval viaceré parametre (počet vojakov, teplota, vzdialenost', smery, geografické súradnice, čas), z dôvodu lepšieho pochopenia kauzality tejto udalosti (Friendly 2008), (obr. 1). Podl’a E. Tufte (2001) ide o najlepší príklad grafiky, aká bola kedy vytvorená.

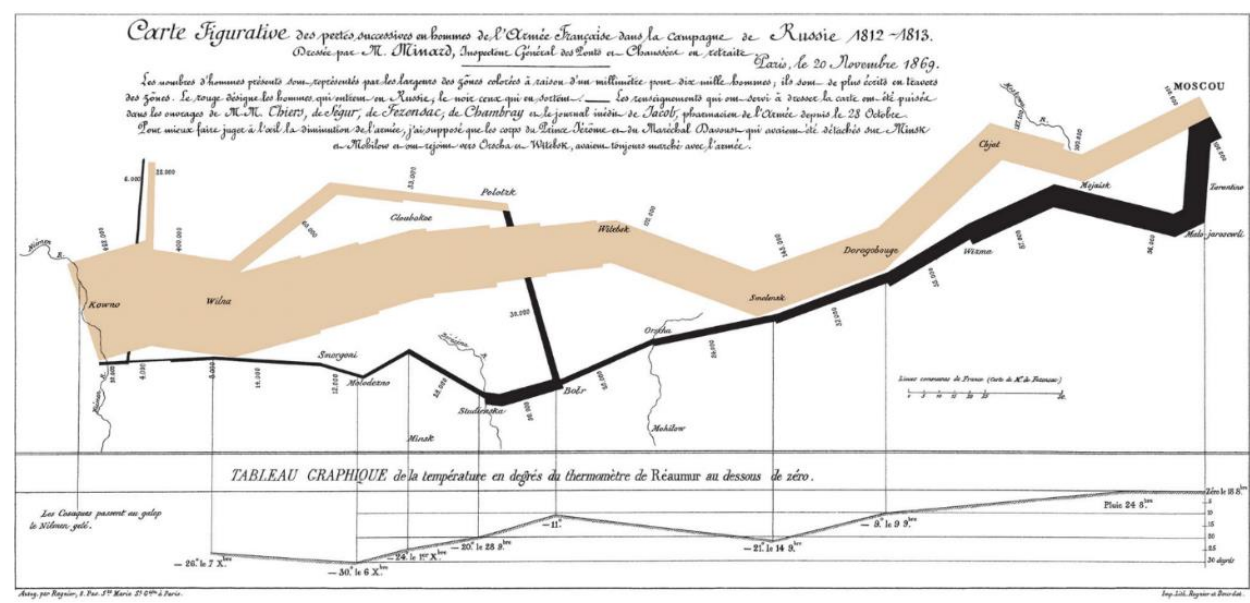

Obr. 1. Práca Charlesa Minarda z roku 1812 mapujúca Napoleonovu inváziu do Ruska Zdroj: Grace (2018) 
Dátová vizualizácia je vel'mi dôležitou súčastou vedeckej práce. V niektorých oblastiach sú vizuálne výstupy absolútnou prioritou, v iných predstavujú podporné mechanizmy pri zhodnotení získaných výsledkov. Každopádne treba konštatovat', že súčasný trend na vizuálne prít’ažlivú prezentáciu (nielen geografických a štatistických dát) je pomerne výrazný, a je preto dôležité venovat' pozornost' tejto oblasti. Často je práve nevhodne zvolená forma vizualizácie, nedodržanie základných pravidiel jej tvorby kl'účovým faktorom pri hodnotení úspechu, resp. neúspechu či už vedecky korektného výstupu, alebo z pohl'adu „online“ sveta (ne)návštevnosti internetovej stránky prezentujúcej svoj obsah zameraný práve na efektívne zobrazenie dát, resp. výsledkov vedeckého výskumu.

\section{Cirkulárna vizualizácia}

V ostatných rokoch sa cirkulárny layout grafického spracovania dát stal pomerne dominantným vo svete dátovej vizualizácie. Dôvody, prečo je tomu tak, prináša príspevok od Lima (2017), ktorý poukazuje na viaceré skutočnosti tejto preferencie z pohl'adu vedeckých štúdií a výskumov zaoberajúcich sa vnímaním tvarov a objektov l'ud'mi. Existuje všeobecná téza prirodzenej preferencie vyhladených kriviek nad ostrými črtami. L'udský organizmus totiž dáva prednost' tvarom a predmetom, ktoré evokujú bezpečnost', čo je charakteristické práve pre vyhladené povrchy a krivky. Naopak predmety s ostrými uhlami a špicovými črtami naznačujú hrozbu a zranenie. Krivka, ktorá je konečným zakriveným tvarom, predstavuje všetky atribúty, ktoré nás prit’ahujú: je to bezpečný, jemný, príjemný, elegantný tvar, ktorý evokuje pokoj a relaxáciu. Tieto tvrdenia sú podchytené viacerými štúdiami. Samotná náklonnost' pre estetickú preferenciu kruhu je teda zakorenená v základoch biológie ako takej. Pri cirkulárnej vizualizácii máme k dispozícii široké spektrum základných vyjadrení, ktoré možno uplatnit' pri znázornení špecifických javov (obr. 2).

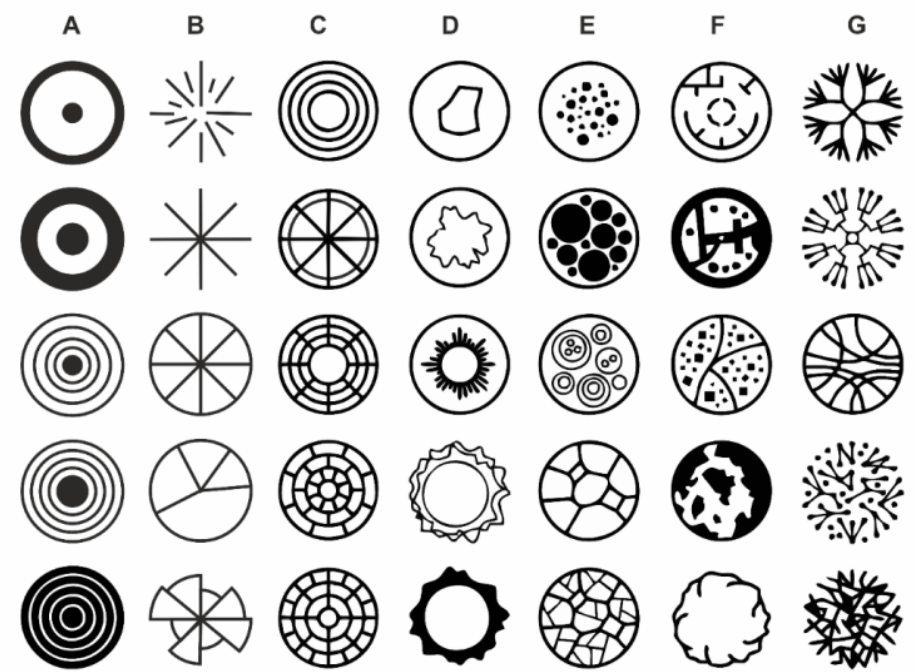

Obr. 2. Príklady cirkulárnej vizualizácie dát (spracované podla Lima 2017) Vysvetlivky: $A$ - kruhy a špirály $\mid B$ - výseky $\mid C$-mriežky a rastre $\mid D$-prírastky, úbytky, toky $\mid E$ - tvary a hranice $\mid F-$ mapy a plány $\mid G$ - uzly a spojenia

V našom príspevku sa zameriame na konkrétnu skupinu a to tzv. "chord diagram”. Na úvod je potrebné venovat' pozornost' základnej terminológii súvisiacej s týmto označením grafickej interpretácie. Tento termín je bežne používaný v anglicky písanej literatúre (Abel, Sander 2014, Andersen a kol. 2016, Flajolet, Noy 2000). Tvorcovia rôznych digitálnych knižníc a programov na vizualizáciu taktiež používajú označenie ako „Radial network diagram”, „Chord layout” (D3) alebo „Dependency wheel” (Highcharts.js). Vychádzajúc z jeho podstaty by bolo 
možné použit' označenie ako cirkulárny diagram, toto pomenovanie sa však hodí na ovel'a väčšie spektrum grafík, ktoré zodpovedajú takémuto označeniu. Naznačeniu existencie väzieb medzi jednotlivými entitami v tomto grafe by mohlo zodpovedat' slovo „súvislost' alebo vzt'ah“. Z tohto by sa dalo teda odvodit' označenie ako „Cirkulárne vyjadrenie súvislosti medzi entitami (uzlami)“ alebo „Cirkulárny diagram súvislosti“, tu sa však dostávame do pomerne zložitého označenia, a vzhl'adom na jasné označenie grafu v anglickej literatúre budeme aj v našom príspevku preferovat' označenie „chord diagram“. Samotná podstata vizualizácie spočíva v znázornení vzájomnej súvzt’ažnosti medzi jednotlivými entitami (priestorové jednotky, osoby, chemické prvky, atd'.), ktorých rozloženie je aranžované v kruhovom zoskupení. Samotné spojenia medzi entitami sú vel'kostne prispôsobené významu daného spojenia (toku). Existuje aj tzv. „,non-ribbon chord diagram“ (bezpruhový chord diagram), ktorý je akousi zjednodušenou verziou chord diagramu, kedy je dôraz položený na znázornenie existencie spojení medzi entitami, ako na ich kvantifikáciu. Samotná kvantifikácia v takomto prípade môže byt' súčast’ou (aj nemusí) grafickej interpretácie symbolu konkrétnej entity (uzla) (obr. 3.).
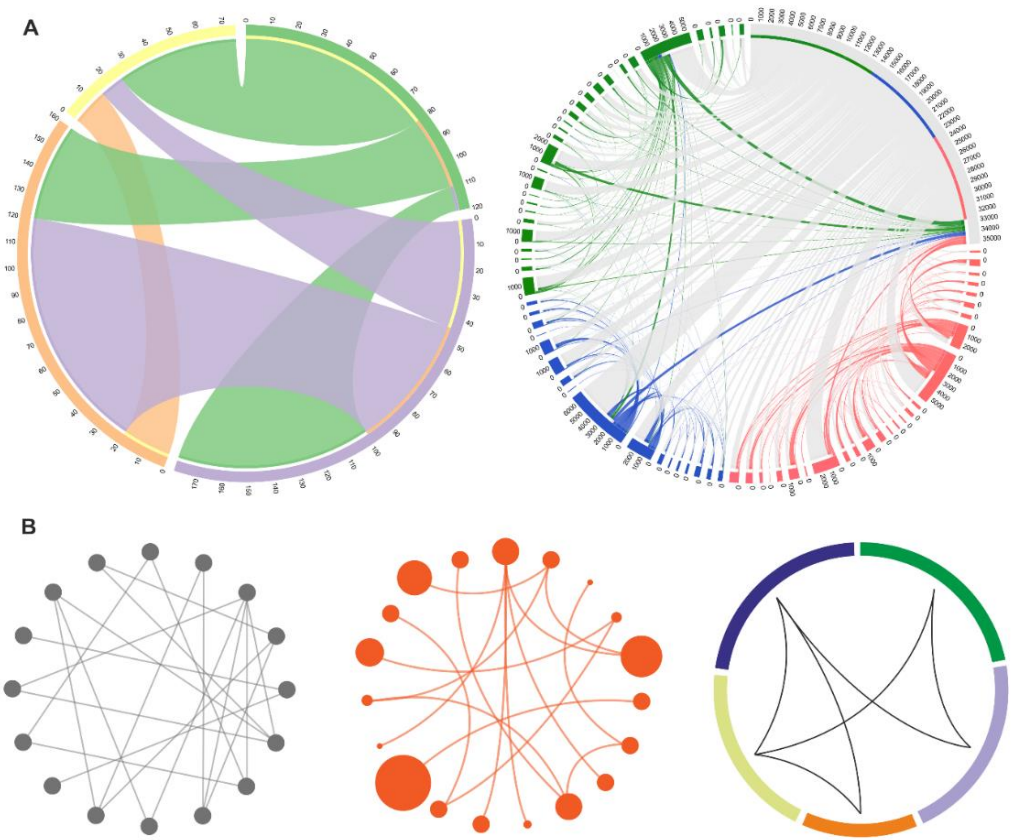

Obr. 3. Porovnanie chord diagramu a bezpruhového chord diagramu (non-ribbon) Vysvetlivky: A - chord diagram |B-,non-ribbon chord diagram “

Vizuálna podoba výsledného diagramu môže na prvý pohl'ad pôsobit' vel'mi zložito, preto treba vysvetleniu jednotlivých elementov venovat' náležitú pozornost' (vid’ čast' „Dáta a použité nástroje“). Vzhl'adom na túto skutočnost' sa ako vhodné javí poukázat' na základnú formu interpretácie takéhoto grafu. Základný spôsob čítania grafu si ukážeme na dvoch príkladoch: Diagram so vzájomným vzt’ahom medzi entitami (dochádzka za prácou medzi jednotlivými mestskými čast'ami) a diagram bez vzájomného vzt'ahu medzi entitami (Dochádzka a odchádzka za prácou a do škôl z jednotlivých mestských častí Bratislavy) (obr. 4). Detailnejšie rozdiely v zápise vstupných dát potrebných pre konštrukciu takýchto diagramov sú rozpísané v d’alšej časti príspevku.

O čitatel'nosti výsledného diagramu rozhoduje viacero faktorov (poradie entít, farebnost' spojení, počet prechodov oblúkom, transparentnost', atd'.), ktoré môže ovplyvnit' priamo tvorca grafiky. Z pohl'adu samotnej realizácie vykreslenia diagramu ide o aplikovanie matematických operácií, ktoré sú integrované v konkrétnej digitálnej knižnici. Niektoré z postupov konštrukcie spojení sú opísané v prácach (Stoimenow 2000, Phan a kol. 2005, Andersen a kol. 2016). 
Jedným z problémov vykreslenia spojení medzi uzlami je ich vel'ké množstvo, ktoré môže byt' súčast'ou vstupných dát. Na zníženie vizuálnej zložitosti takéhoto znázornenia sa používa technika zvaná hierarchické zoskupovanie hrán (Holten 2006, Zhou a kol. 2013). Jednou z možností ako eliminovat' vel'ké množstvo spojení medzi entitami je upriamit' pozornost' čitatel'a na podstatné informácie z diagramu, resp. na tie, ktoré považujeme z hl'adiska interpretácie za klúčové. Toto možno dosiahnut primárnou editáciou parametrov diagramu a jeho výslednou úpravou (obr. 5). V prípade online riešenia máme výraznejšie možnosti identifikovat' entity s vel'mi nízkymi hodnotami. Tu je vhodné využit’ interaktivitu, animácie výsledného grafu, eventuálne vypnutie menej podstatných uzlov.
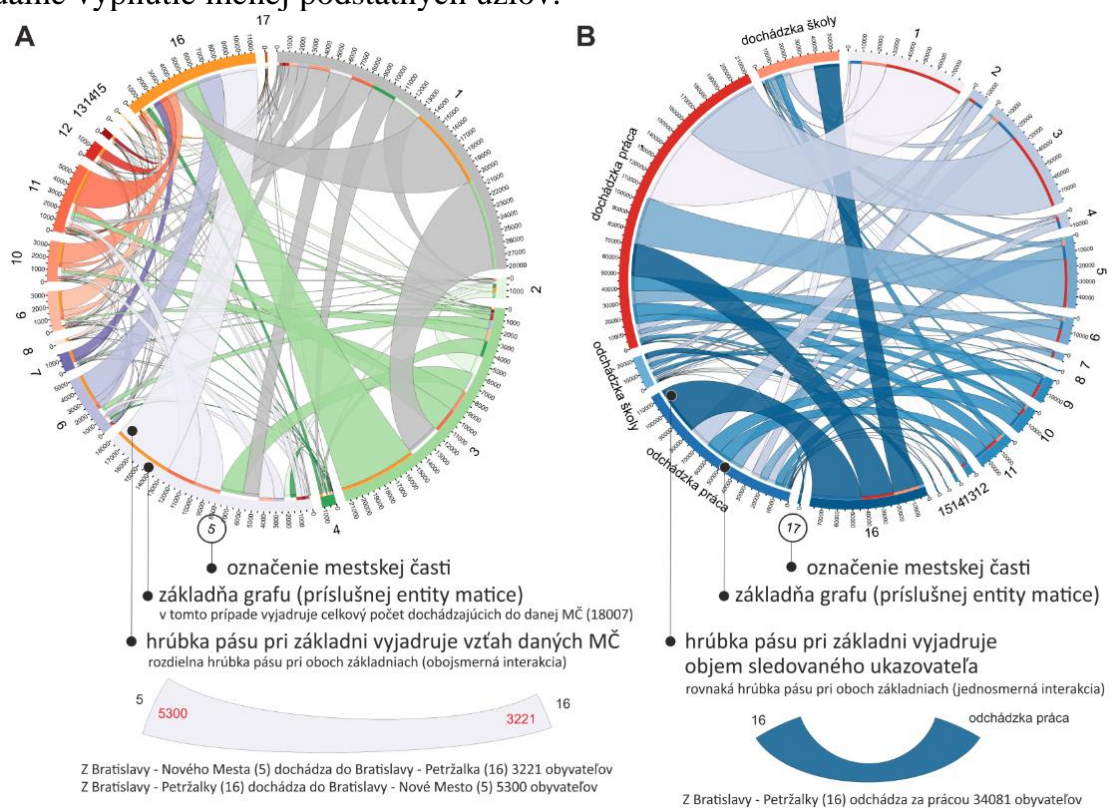

Obr. 4. Príklad čitania chord diagramu

Vysvetlivky: $A$ - vzájomný vzt'ah medzi entitami $\mid B$ - bez vzájomného vzt'ahu medzi entitami Pôvodný obrázok vo väčšom rozlíšeni uvádza Bačík (2019a)
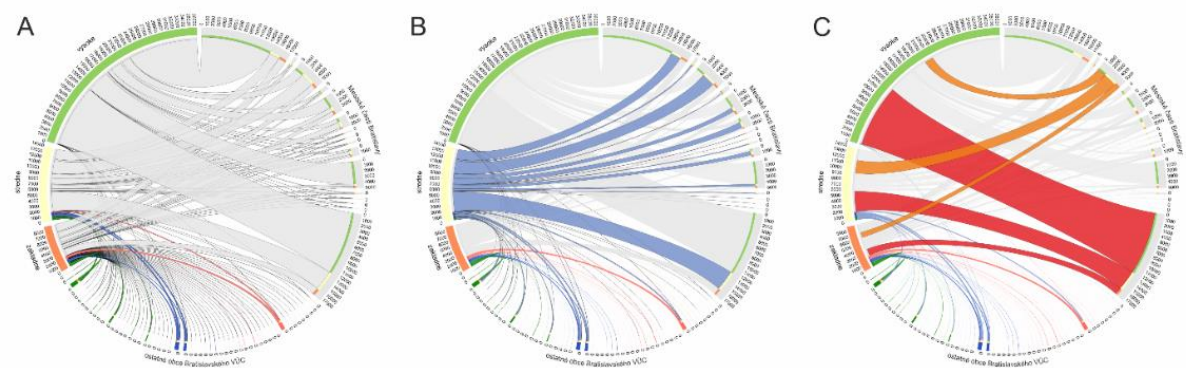

Obr. 5. Rôzne preferencie zobrazenia dát v chord diagrame po úprave

Vysvetlivky: A - primárny grafický výstup bez editácie elementov $\mid B, C$-diagram po editácii, so zacielením na konkrétne dáta

Primárne sa použitie chord diagramov uplatňuje pri vizualizácii objektov, medzi ktorými existuje priamy vzt'ah. V demografii využili tento koncept ako prví Abel, Sander (2014), Sander a kol. (2014), ktorí znázornili týmto grafickým vyjadrením svetovú migráciu. Práve migračné a dochádzkové dáta sú vel'mi vhodné na použitie chord diagramov, nakol'ko dobre ilustrujú vzájomné vzt'ahy medzi destinačnými a ciel’ovými oblast'ami. Chord diagram je však 
možné použit' aj v prípadoch kedy medzi entitami neexistuje vzájomná interakcia a ide v podstate o jednoduchú kvantifikáciu dát (podobne ako v stípcovom grafe). Jeden súbor entít môže predstavovat' konkrétne jednotky (napr. regióny) a d'alšie entity kategórie sledované v grafe (vid’. Obr. 4B). Ako príklad použijeme znázornenie odchádzky za prácou podl’a dížky trvania v obciach Bratislavského VÚC ${ }^{1}$ (obr. 6.).

A

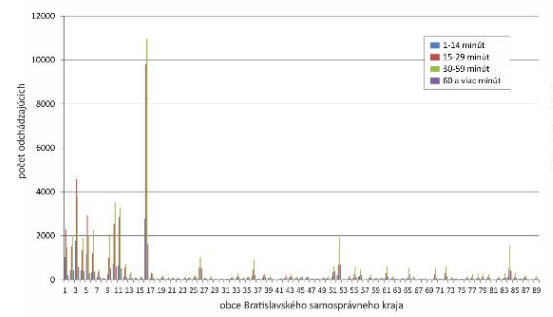

B

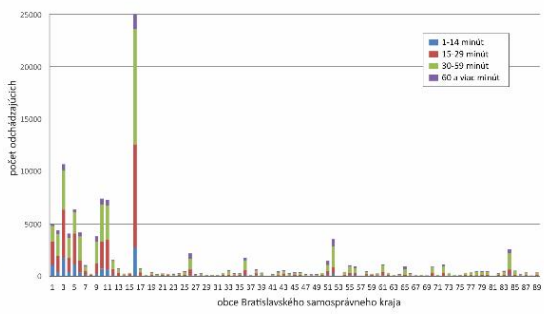

C

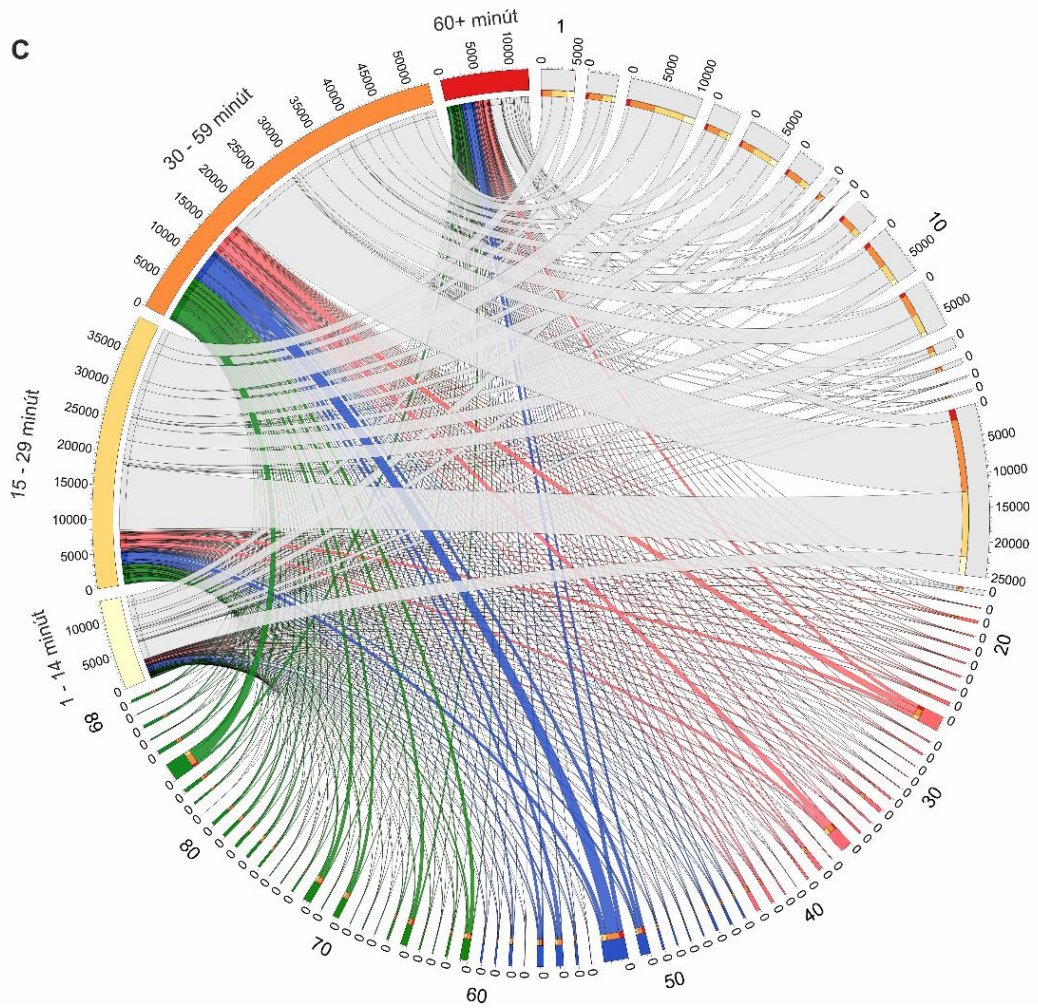

Obr. 6. Porovnanie stípcového, skladaného grafu a chord diagramu zobrazujúceho odchádzku podl'a dížky trvania (Š́rka základne diagramu pri jednotlivých obciach predstavuje celkový počet denne odchádzajúcich za prácou z danej obce a širka základne pri časových intervaloch vyjadruje celkový objem odchádzajúcich v danom časovom intervale z obcí Bratislavského VÚC); Vysvetlivky: A - Stípcový graf (os $x$ - obce Bratislavského VÚC, os y-počet odchádzajúcich $v$ danom ćasovom intervale) $\mid B$-Skladaný graf (os $x$-obce Bratislavského VÚC, os y-počet odchádzajúcich v danom časovom intervale) $\mid C$-Chord diagram (v smere hodinových ručičiek: Čisla 1 - 89 označujú obce Bratislavského VÚC, d’alej nasledujú počty odchádzajúcich v daných časových intervaloch;

\footnotetext{
${ }^{I}$ VÚC - Vyšši územný celok. V príspevku použivame aj označenie samosprávny kraj, ktorý z pohladu organizácie verejnej správy vyjadruje tú istú územnú jednotku.
} 
V tomto prípade sú spojenia znázornené len medzi danou obcou a konkrétnymi časovými kategóriami (nie medzi obcami navzájom). Pri použití klasického stĺpcového, resp. skladaného grafu, môžeme identifikovat' objem odchádzky za konkrétny čas pre konkrétne obce, avšak pri použití chord diagramu vieme okamžite identifikovat' okrem parciálnych počtov aj celkový objem odchádzajúcich v konkrétnom časovom intervale. V uvedenom grafe je to skutočnost', že väčšine žiakov trvá cesta do školy v rozpätí 30 - 59 minút. Pri použití štandardného grafického vyjadrenia ostáva tento údaj viac-menej ukrytý, resp. identifikácia tohto objemu je pomerne náročná. Rovnako tak, ako vidiet' z obrázku, možno konštatovat', že pri väčšom počte entít je vhodnejšie používat' náhradu štandardných grafov, nakol'ko počet zobrazovaných jednotiek na osi $x$ (obce Bratislavského VÚC) je z hl'adiska jednoduchosti interpretácie pomerne limitujúci.

Na záver krátka poznámka $\mathrm{k}$ histórii používania chord diagramov. $\mathrm{V}$ úvode príspevku sme spomenuli, že samotná problematika dátovej vizualizácie siaha niekol'ko storočí do minulosti. Z tohoto pohl'adu je nami sledovaný chord diagram skutočným „nováčikom“ medzi rozličnými grafikami. Prvý chord diagram bol publikovaný v roku 2007 v New York Times a zobrazoval detailné informácie o genóme. Od tohto obdobia však jeho využitel'nost' výrazne narástla a stala sa súčast’ou vizualizácie javov takmer vo všetkých vedných disciplínach opisujúcich rozličné formy vzt’ahov medzi objektami, geografiu nevynímajúc. Popularita takéhoto grafického vyjadrenia vyústila aj do priamej implementácie výpočtov potrebných pre zobrazenie chord diagramov do rozličných programov a vizualizačných knižníc. Z mnohých nástrojov možno menovat' napríklad Flourish, amCharts, Tableau, R, ZingChart, Highcharts, D3 a Circos. Práve posledné dva menované produkty sme použili aj v našej vizualizácii dochádzkových vzt’ahov na príklade obcí Bratislavského VÚC.

\section{Dáta a použité nástroje}

Pri tvorbe nášho príspevku sme využili dáta o dochádzke zo Sčítania obyvatel’ov, domov a bytov z roku 2011. Sme si vedomí, že práve niektoré dáta týkajúce sa dennej dochádzky do práce boli pri tomto sčítaní podrobené pomerne výraznej kritike, avšak pre naše účely a vzhl'adom na použitú mierku ich spracovania (obce BA VÚC) boli postačujúce. Podoba originálneho vstupného súboru je na obr. 7.

\begin{tabular}{|c|c|c|c|c|c|c|c|c|c|c|c|c|c|c|c|}
\hline 4 & A & B & c & D & E & $\mathrm{F}$ & G & $\mathrm{H}$ & I & $\mathrm{J}$ & $\mathrm{K}$ & $\mathrm{L}$ & M & $\mathrm{N}$ & 0 \\
\hline 1 & & & & & & & & & & & & & & & \\
\hline $\begin{array}{l}2 \\
3\end{array}$ & TAB. 702 Bývajúce obyvatePstvo o & chádzajúc & do zame & tnania a s & kôl podfa & sohlavia a & reku a po & Pa obce or & Ichádzky a & obce doc & ládzky & & & & SODB 2011 \\
\hline 4 & Obec odchádzky & & & vatel'stivo e & Konomicky a & ktivne odchá & dzajúce do & zamestnani & & & & Żiacia & a študenti & & Odchádzka \\
\hline 5 & obec dochádzky & muži & Ženy & spolu & & & $\mathrm{v}$ tom $\mathrm{v}$ & veku & & & spolu & & $z$ toho & & spolu \\
\hline 6 & & & & & $15-24$ & $25-29$ & $30-34$ & $35-44$ & $45-59$ & $60+$ & & žiaci Zś & študenti SŚ & š̃tudenti Vś| & \\
\hline 7 & $\mathrm{a}$ & 1 & 2 & 3 & 4 & 5 & 6 & 7 & 8 & 9 & 10 & 11 & 12 & 13 & 14 \\
\hline 8 & & & & & & & & & & & & & & & \\
\hline 9 & OKRES HLOHOVEC & & & & & & & & & & & & & & \\
\hline 10 & Úhrn odchádzajúcich v okrese & 5371 & 4056 & 9427 & 772 & 1457 & 1473 & 2674 & 2863 & 188 & 2795 & 594 & 1122 & 1079 & 12222 \\
\hline 11 & v tom: odchádzajúci v rámci okresu & 1886 & 1610 & 3496 & 238 & 352 & 491 & 1109 & 1228 & 78 & 734 & 433 & 273 & 28 & 4230 \\
\hline 12 & odchádzajúci do iných okresov SR & 3211 & 2206 & 5417 & 498 & 981 & 822 & 1442 & 1569 & 105 & 1972 & 153 & 840 & 979 & 7389 \\
\hline 13 & z toho okres: & & & & & & & & & & & & & & \\
\hline 14 & Bratislava hl.m. SR & 783 & 456 & 1239 & 96 & 337 & 218 & 305 & 264 & 19 & 342 & 7 & 22 & 313 & 1581 \\
\hline 15 & Košice - mesto & 1 & 2 & 3 & 0 & 0 & 1 & 2 & 0 & 0 & 4 & 0 & 0 & 4 & \\
\hline 16 & Bánovce nad Bebravou & 3 & 2 & 5 & 1 & 0 & 1 & 1 & 2 & 0 & 2 & 2 & 0 & 0 & 7 \\
\hline 17 & Banská Bystrica & 6 & 1 & 7 & 2 & 0 & 2 & 1 & 1 & 1 & 20 & 0 & 0 & 20 & 27 \\
\hline 18 & Brezno & 2 & 0 & 2 & 0 & 1 & 1 & 0 & 0 & 0 & 0 & 0 & 0 & 0 & 2 \\
\hline 19 & Ćadca & 1 & 0 & 1 & 0 & 0 & 1 & 0 & 0 & 0 & 2 & 0 & 1 & 1 & 3 \\
\hline 20 & Dunajská Streda & 5 & 0 & 5 & 0 & 1 & 0 & 1 & 3 & 0 & 1 & 0 & 1 & 0 & 6 \\
\hline 21 & Galanta & 137 & 116 & 253 & 25 & 40 & 31 & 60 & 92 & 5 & 32 & 4 & 21 & 7 & 285 \\
\hline 22 & llava & 4 & 0 & 4 & 0 & 0 & 2 & 0 & 1 & 1 & 0 & 0 & 0 & 0 & 4 \\
\hline 23 & Komárno & 0 & 1 & 1 & 0 & 0 & 0 & 1 & 0 & 0 & 0 & 0 & 0 & 0 & 1 \\
\hline 24 & Levice & 23 & 3 & 26 & 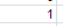 & 5 & 2 & 4 & 13 & 1 & 1 & 0 & 1 & 0 & 27 \\
\hline 25 & Levoča & 1 & 1 & 2 & 0 & 0 & 0 & 0 & 2 & 0 & 0 & 0 & 0 & 0 & 2 \\
\hline 26 & Liptovský Mikuláš & 0 & 1 & 1 & 0 & 0 & 0 & 0 & 1 & 0 & 0 & 0 & 0 & 0 & 1 \\
\hline 27 & Malacky & 19 & 4 & 23 & 2 & 4 & 8 & 5 & 4 & 0 & 2 & 2 & 0 & 0 & 25 \\
\hline 28 & Martin & 3 & 1 & 4 & 0 & 1 & 0 & 0 & 2 & 1 & 1 & 0 & 0 & 1 & 5 \\
\hline 29 & Michalovce & 1 & 0 & 1 & 0 & 0 & 0 & 0 & 1 & 0 & 0 & 0 & 0 & 0 & 1 \\
\hline 30 & Myjava & 5 & 1 & 6 & 0 & 0 & 1 & 3 & 2 & 0 & 1 & 0 & 0 & 1 & \\
\hline 31 & Ni & 188 & 188 & 376 & 41 & 67 & 55 & 101 & 107 & 5 & 320 & 2 & 67 & 251 & 696 \\
\hline 32 & Nové Mesto nad Vảhom & 29 & 34 & 63 & 7 & 9 & 13 & 16 & 18 & 0 & 6 & 2 & 4 & 0 & 69 \\
\hline 33 & Nové Zám & 8 & 0 & 8 & 0 & 1 & 3 & 2 & 2 & 0 & 0 & 0 & 0 & 0 & 8 \\
\hline 34 & Partizánske & 1 & 0 & 1 & 0 & 0 & 1 & 0 & 0 & 0 & 0 & 0 & 0 & 0 & 1 \\
\hline 35 & Pezinok & 28 & 8 & 36 & 5 & 8 & 4 & 12 & 7 & 0 & 14 & 0 & 10 & 4 & 50 \\
\hline 36 & Pieštany & 310 & 344 & 654 & 59 & 104 & 88 & 177 & 214 & 12 & 268 & 30 & 217 & 21 & 922 \\
\hline 37 & Považská Bystrica & 6 & 0 & 6 & 0 & 3 & 1 & 1 & 1 & 0 & 0 & 0 & 0 & 0 & 6 \\
\hline 38 & Preš & 3 & 0 & 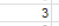 & 0 & 0 & 0 & 2 & 1 & 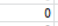 & 1 & 1 & 0 & 0 & 4 \\
\hline 39 & & 2 & 1 & 3 & 0 & 0 & 0 & 1 & 2 & 0 & 0 & 0 & 0 & 0 & 3 \\
\hline 40 & $P$ & 0 & 0 & 0 & 0 & 0 & 0 & 0 & 0 & 0 & 1 & 0 & 0 & 1 & 1 \\
\hline 41 & Rimavská Sobota & 3 & 2 & 5 & 5 & 0 & 0 & 0 & 0 & 0 & 0 & 0 & 0 & 0 & 5 \\
\hline 42 & Ružomberok & 1 & 1 & 2 & 1 & 1 & 0 & 0 & 0 & 0 & 3 & 0 & 0 & 3 & 5 \\
\hline 43 & Senec & 34 & 30 & 64 & 4 & 12 & 9 & 18 & 20 & 1 & 3 & 0 & 3 & 0 & 67 \\
\hline 44 & Senica & 7 & 2 & 9 & 1 & 2 & 3 & 0 & 3 & 0 & 4 & 0 & 3 & 1 & 13 \\
\hline 45 & Skalica & 1 & 2 & 3 & 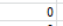 & 2 & 1 & 0 & 0 & 0 & 2 & 0 & 0 & 2 & 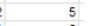 \\
\hline 46 & Šala & 4 & 3 & 7 & n & ? & 1 & 0 & 3 & 1 & 1 & n & 1 & $n$ & 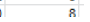 \\
\hline
\end{tabular}

Obr. 7. Ukážkový hárok vstupného súboru o dochádzke 
Samotný súbor obsahuje 4 hárky (2 pre údaje o dochádzke a 2 pre údaje o odchádzke). Štruktúra jednotlivých hárkov nám vyhovovala z hl'adiska sledovaných atribútov o dochádzke a odchádzke, ktoré sme následne vizualizovali pomocou chord diagramov. Pri oboch procesoch vieme z týchto dát zistit' množstvo ukazovatel'ov: počet mužov a žien podiel'ajúcich sa na dochádzke, ich vekovú štruktúru, čas dochádzky v minútach ako aj odvetvie hospodárstva (pri dochádzke podla ekonomickej činnosti), resp. typ školy (pri hodnotení dochádzky do škôl). Okrem toho samozrejme nájdeme smery dochádzky pre každú jednotlivú obec. Vzhl'adom na skutočnost', že tieto dáta prezentujeme aj online v podobe internetovej stránky (http://www.sodbtn.sk/dochadzka_ba), bolo potrebné pri spracovaní dát využit' množstvo viacerých metód a postupov (prirad’ovanie kódov obcí do atribútov, zápis do databázových tabuliek na server, SQL funkcie výpisu dát pre konkrétnu obec, prenos premenných medzi stránkami a pod.) V našom príspevku sa však zameriavame na využitie cirkulárnej vizualizácie týchto dát (pomocou chord diagramov), a preto sa nebudeme týmto dielčím postupom detailnejšie venovat'. Zameriame sa na opis online rozhrania „Circos“, pomocou ktorého možno vytvárat' chord diagramy a tieto výstupy d’alej editovat' podl'a potreby, ako aj na využitie knižnice D3, pomocou ktorej sme vytvárali interaktívne verzie chord diagramov z predmetných dát a následne distribuovali v prostredí Internetu.

\section{Online aplikácia Circos}

Circos je softvérový balík na vizualizáciu údajov a informácií, ktoré vizualizuje v kruhovom usporiadaní, čím je vzhl’adom na súčasné trendy v oblasti grafickej vizualizácie vel'mi atraktívny (Krzywinski a kol. 2009). Tvorcom projektu Circos je Martin Krzywinski (Genome Sciences Center) a všetky potrebné informácie možno nájst' práve na stránkach vytvorených autorom projektu (http://circos.ca). Pôvodne bol navrhnutý na vizualizáciu genomických údajov, avšak jeho popularita vel'mi rýchlo narástla a je vhodný pre akýkol'vek odbor v oblasti vedy alebo umenia, o čom svedčí aj obrovské množstvo dostupných vizualizácií vytvorených v tomto programe, ktoré sú dostupné priamo na stránkach produktu. Je určený pre všetkých, ktorí chcú znázornit' alebo preskúmat' vel'ké množstvo údajov. V prípade našich dát sme využili online nástroj „TableViewer“, ktorý je dostupný na stránkach projektu Circos (Krzywinski et al. 2009). Tento nástroj pracuje s dátami zapísanými v podobe matice vo formáte *.txt, pričom jednotlivé hodnoty musia byt' oddelené tabulátormi. Výsledok si môžeme ukázat' na modelovom príklade piatich imaginárnych regiónov (A - E), medzi ktorými existujú isté vzt’ahy. Môžeme si pod týmito prvkami predstavit' jednotlivé obce, medzi ktorými znázorn̆ujeme vzájomné dochádzkové väzby. Štruktúra vstupných dát je zobrazená v tab. 1.

Tab. 1. Zápis dát potrebných pre ich cirkulárnu vizualizáciu v prostredí CIRCOS

\begin{tabular}{|c|c|c|c|c|r|r|r|}
\hline data & data & data & \multicolumn{1}{c|}{6} & \multicolumn{1}{c|}{7} & \multicolumn{1}{c|}{8} & \multicolumn{1}{c|}{9} & \multicolumn{1}{c|}{10} \\
\hline data & data & data & $127,201,127$ & $190,174,212$ & $253,192,134$ & $255,255,153$ & $56,108,176$ \\
\hline data & data & data & A & B & C & D & \multicolumn{1}{c|}{ E } \\
\hline 1 & $127,201,127$ & A & 0 & 2940 & 32 & 332 & 154 \\
\hline 2 & $190,174,212$ & B & 3852 & 0 & 103 & 427 & 1234 \\
\hline 3 & $253,192,134$ & $\mathrm{C}$ & 159 & 223 & 0 & 19 & 0 \\
\hline 4 & $255,255,153$ & D & 1979 & 2111 & 115 & 0 & 531 \\
\hline 5 & $56,108,176$ & E & 53 & 44 & 0 & 36 & 0 \\
\hline
\end{tabular}

označenie poradia v akom sa vykresl'ujú jednotlivé segmenty

farebné označenie segmentov (RGB zápis)

jednotlivé segmenty matice

Samotné dáta nemusia obsahovat' stípce označenia poradia v akom sa vykresl'ujú, ani hodnoty farieb príslušných elementov v podobe zápisu príslušného RGB kódu. Pri ich absencii je farba a poradie doplnená automaticky. Z užívatel'ského hl'adiska je však vhodnejšie tieto hodnoty zahrnút' do vstupnej matice. V prípade nekorektného zápisu dát sa zobrazí namiesto 
výsledného chord diagramu hlásenie, ktoré nás upozorní na chybu v dátach. Pri korektnom zápise vstupných hodnôt je výsledkom základná podoba chord diagramu, ktorého jednotlivé položky sú vysvetlené na obr. 8 .

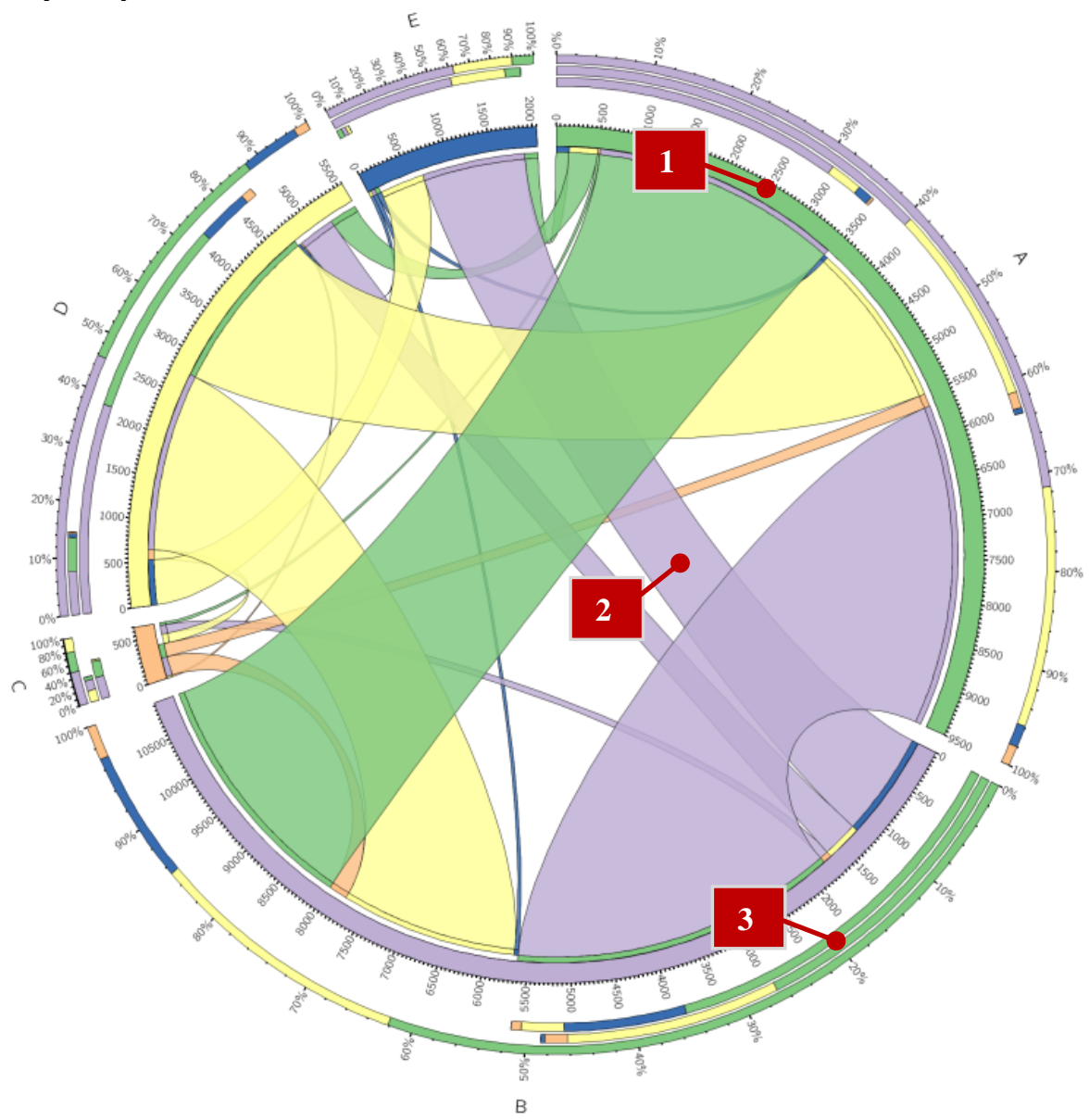

Obr. 8. Základná podoba chord diagramu generovaného službou CIRCOS pri správnom nastavení vstupných hodnôt

Vysvtlivky: 1 -Segmenty riadkov a stípcov matice; 2 - Śírka pruhu (ribbon) zobrazuje hodnotu bunky spojenej s párom segmentu riadok/stípec; 3 -Relatívne vyjadrenie riadku, stípca a celkovo pre každý segment

Primárne nastavenie parametrov vykreslenia však vo väčšine prípadov nevytvorí diagram, ktorý by bol vhodný pre zobrazenie nami požadovaných informácií. A preto je súčastou tohto online produktu aj uživatel'ské rozhranie, v ktorom môže tvorca diagramov nastavit' preferenciu výsledného diagramu. Takéto porovnanie medzi základným nastavením upravenými parametrami diagramu možno vidiet' na obr. 9 , v ktorom je znázornená dochádzka za prácou medzi jednotlivými mestskými čast’ami Bratislavy.

Výsledná podoba diagramu teda závisí od príslušných nastavení, ktoré sú dostupné pri využití online služby. Okrem toho je možné nainštalovat' aj samotný program CIRCOS, ktorý ponúka ešte výraznejšie možnosti výslednej vizualizácie. Samotný výsledný výstup je generovaný ako obrázok vo formáte PNG, ale zároveň aj vo vektorovom formáte SVG. Tento možno načítat' v akomkol'vek vektorovom grafickom programe, čo nám dáva vel'ký priestor pre d'alšiu editáciu a modifikáciu diagramu tak, aby zodpovedal tomu, čo chceme primárne danou vizualizáciou ukázat'. 

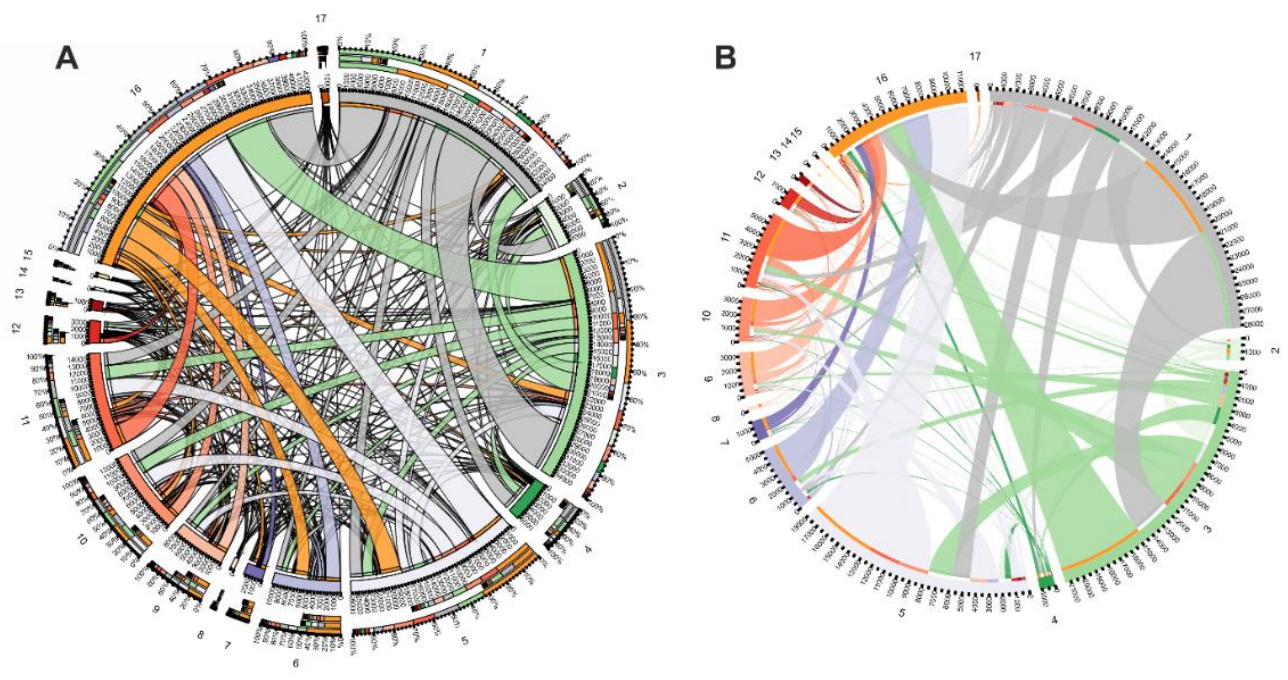

Obr. 9. Rôzne nastavenie atribútov chord diagramu vytvoreného pomocou Circos-u Vysvetlivky: A - originálne nastavenie zobrazenia $\mid B$ - modifikácia vstupných parametrov (skrytie relatívneho vyjadrenia, usporiadanie pruhov pre jednotlivé segmenty vzostupne, vyfarbenie pruhov podl'a riadku v matici, odstránené orámovanie elementov grafu a racionalizované vykreslenie pruhov; Názvy mestských častí (v smere hodinových ručičiek): 1 -Bratislava-Staré Mesto 2 -Bratislava-Podunajské Biskupice $\mid 3$-Bratislava-Ružinov|4-Bratislava-Vrakuňa |5-Bratislava-Nové Mesto | 6-Bratislava-Rača | 7 -Bratislava-Vajnory| 8-BratislavaDevín | 9-Bratislava-Devínska Nová Ves $\mid 10$-Bratislava-Dúbravka| 11 -Bratislava-Karlova Ves $\mid 12$ - Bratislava-Lamač | 13 - Bratislava-Záhorská Bystrica|14-Bratislava-Čunovo | 15 -Bratislava-Jarovce |16-Bratislava-Petržalka|17-Bratislava-Rusovce

\section{D3 knižnica}

Pri výbere nástroja vhodného pre interaktívnu verziu chord diagramov zohrávala úlohu samotná znalost' prostredia, v ktorom sa daný diagram vytvára. Ako už bolo spomínané v úvode, dynamické chord diagramy možno vytvárat' pomocou viacerých nástrojov. Digitálna knižnica D3 už istý čas predstavuje dynamický prístup k vizualizácii geografických údajov (aj negeografických, resp. nepriestorových dát) publikovaných cez webové rozhranie. Pomocou D3 môžu vývojári spájat' vstupné dáta do l'ubovol'ných prvkov dokumentu, aplikovat' dynamickú transformáciu a modifikovat' ich obsah (Bostock, Ogievetsky, Heer, 2011). Chord diagramy vytvorené pomocou tejto knižnice sú na rozdiel od diagramov vytvorených pomocou Circos-u, interaktívne a umožňujú tak detailné zobrazenie akejkol’vek informácie v grafe. Aplikácia tejto knižnice je výhodná práve vzhl'adom na možnosti priamej interakcie klienta s diagramom. Dôležitým momentom pri výbere D3 knižnice bola aj skutočnost', že zdrojové dáta môžu byt' zapísané vo forme matice (s modifikáciou zápisu kompatibilného s príslušnými funkciami knižnice), práve tak, ako tomu bolo pri vstupných súboroch potrebných pre vytvorenie diagramov pomocou Circos-u. Príklad si ukážeme na rovnakých dátach, ako tomu bolo v prípade chord diagramu vytváraného pomocou Circos-u (ide o dáta z tab. 1) (obr. 10).

Výsledný diagram automaticky využíva racionalizované vykreslenie pruhov, t. z., že hrúbka pruhu na jednom konci je iná ako na druhom. Inými slovami povedané, hrúbka pásu na oboch koncoch zodpovedá reálnym hodnotám sledovaného ukazovatel’a v smere ,z“ „do“. Farebné znázornenie jednotlivých segmentov a pruhov je napísané vo vstupnom súbore v hexadecimálnom zápise. Hlavnou výhodou je interaktivita diagramu, kedy možno zobrazit' presné dielčie hodnoty jednotlivých pruhov, ako aj segmentov vstupnej matice. 

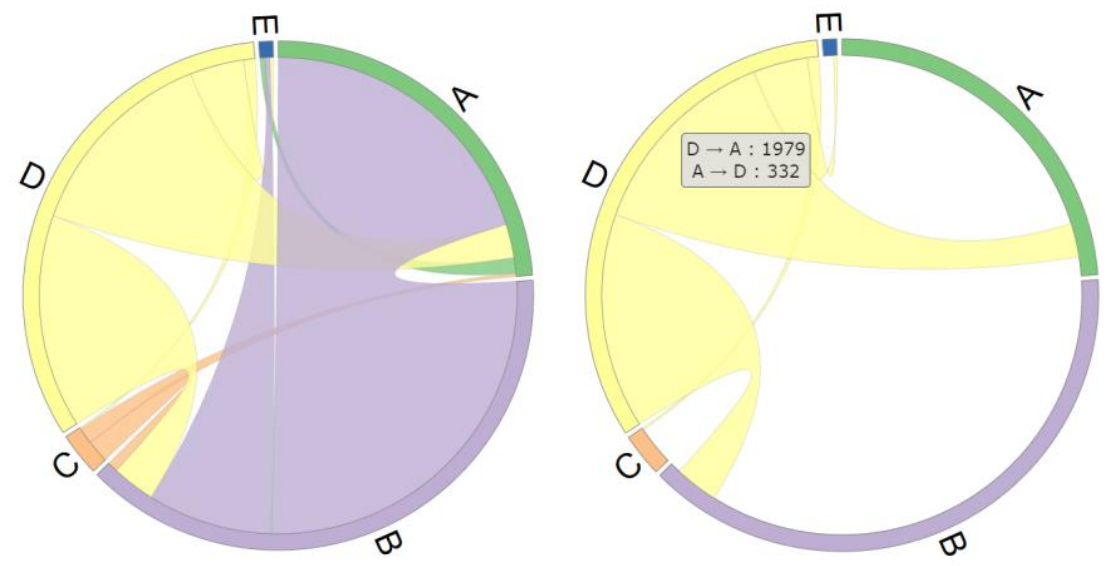

Obr. 10. Chord diagram vytvorený pomocou knižnice D3

\section{Výsledky}

Naším ciel'om bolo vytvorenie série grafov (chord diagramov), ktoré by prezentovali vybrané atribúty dát o dochádzke za prácou a do škôl medzi jednotlivými obcami Bratislavského VÚC. Ked’že primárne sme sa snažili o interpretáciu týchto dát v online prostredí, dominovalo využitie knižnice D3 a jej funkcií pred diagramami vytváranými v prostredí Circos (príklady uvádza Bačík 2019b) . Tento je ovel’a vhodnejšie použit’ pri printovej prezentácii dát v podobe rôznych posterov a infografík, s možnost'ou editácie diagramu tak, aby jeho výpovedná hodnota bola zacielená na klúčové prvky zobrazované v týchto diagramoch (dôraz na vybrané charakteristiky, ktoré autor považuje za relevantné z hl'adiska získaných výsledkov). Celkovo bolo na základe vstupných dát vytvorených 21 chord diagramov, ktoré možno rozdelit' do dvoch skupín - so vzájomnou interakciou vstupných entít a bez vzájomnej interakcie vstupných entít (tab. 2, obr. 11).

Tab. 2. Zoznam chord diagramov dostupných na stránke www.sodbtn.sk/dochadzka ba (Bačík2019c)

\begin{tabular}{|c|c|c|}
\hline \multirow[t]{15}{*}{ Bez vzájomnej interakcie } & 1 & Denná odchádzka z obcí BA kraja podl’a času trvania \\
\hline & 2 & Odchádzka z obcí BA kraja podla odvetvia hospodárstva \\
\hline & 3 & Odchádzka z obcí BA kraja podl'a veku \\
\hline & 4 & Odchádzka z obcí BA kraja do škôl \\
\hline & 5 & Odchádzka z obcí BA kraja do zamestnania a do škôl \\
\hline & 6 & Denná dochádzka do obcí BA kraja podla času trvania \\
\hline & 7 & Dochádzka do obcí BA kraja podla odvetvia hospodárstva \\
\hline & 8 & Dochádzka do obcí BA kraja podla veku \\
\hline & 9 & Dochádzka do obcí BA kraja do škôl \\
\hline & 10 & Dochádzka do obcí BA kraja do zamestnania a do škôl \\
\hline & 11 & Dochádzajúci a odchádzajúci do práce a do škôl v obciach BA kraja \\
\hline & 12 & Dochádzajúci a odchádzajúci do práce a do škôl v mestských častiach Bratislavy \\
\hline & 13 & Dochádzajúci a odchádzajúci do práce a do škôl v obciach okresu Malacky \\
\hline & 14 & Dochádzajúci a odchádzajúci do práce a do škôl v obciach okresu Pezinok \\
\hline & 15 & Dochádzajúci a odchádzajúci do práce a do škôl v obciach okresu Senec \\
\hline \multirow[t]{6}{*}{ So vzájomnou interakciou } & 16 & Odchádzka za prácou v okresoch SR (2011) (do iných okresov) \\
\hline & 17 & Dochádzka za prácou v okresoch SR (2011) (z iných okresov) \\
\hline & 18 & Odchádzajúci v obciach BA kraja medzi sebou \\
\hline & 19 & Dochádzajúci v obciach BA kraja medzi sebou \\
\hline & 20 & Odchádzajúci v mestských častiach BA medzi sebou \\
\hline & 21 & Dochádzajúci v mestských častiach BA medzi sebou \\
\hline
\end{tabular}


$\mathrm{V}$ prvom prípade ide teda o diagramy, znázorňujúce dochádzkové toky z miesta $\mathrm{A}$ do miesta $\mathrm{B}$, a zároveň $\mathrm{z}$ miesta $\mathrm{B}$ do miesta $\mathrm{A}$. Hodnoty dochádzky/odchádzky sú vykreslené rôznou hrúbkou pruhu pri základni danej obce. $\mathrm{V}$ druhej skupine diagramov ide o znázornenie konkrétnych atribútov dochádzky (čas, vek, odvetvie hospodárstva, atd'.), a teda nejde o obojsmernú interakciu, sledovaná je konkrétna sumárna hodnota atribútu (čas dochádzky zo všetkých obcí, počet žiakov základných a stredných škôl, atd'.)

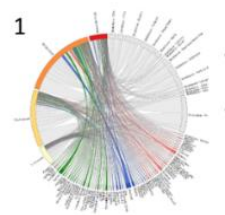

7
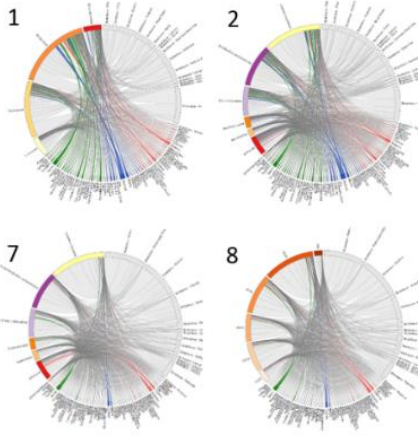

8
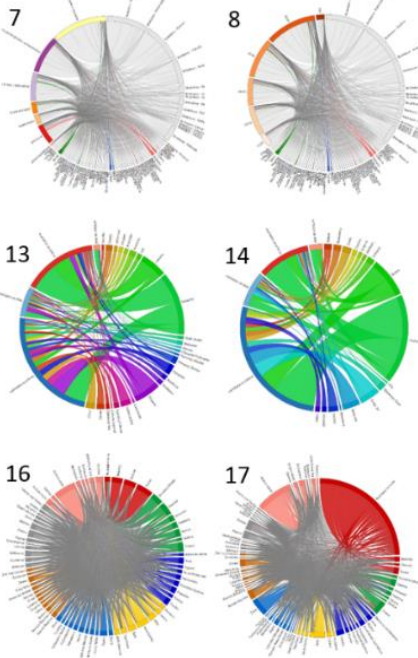

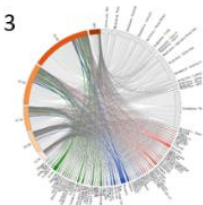

9
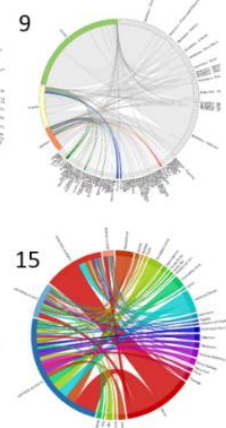
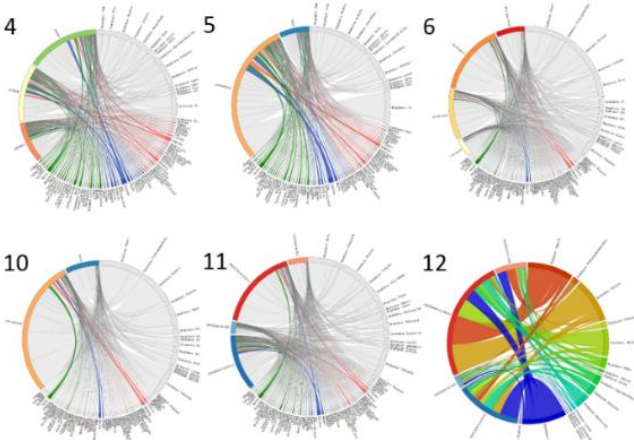

Obr. 11. Ukážky výsledných interaktívnych chord diagramov

Okrem atraktívneho kruhového usporiadania je najdôležitejším prvkom vytvorených chord diagramov interaktívnost', možnost' získat' konkrétnu hodnotu pre konkrétny dochádzkový atribút. Kompletná funkcionalita vykreslenia jednotlivých elementov je súčast'ou použitej D3 knižnice a využitie jej výhod je možné bez akéhokol'vek zásahu do jej vnútorného obsahu. Modifikácia výsledného vzhl'adu a zobrazenia dát je možná pomocou jednoduchých úprav zdrojového kódu v JavaScripte. Zobrazenie elementov a spojovacích pruhov vychádza z dvoch vstupných súborov, ktoré sú potrebné pre vykreslenie chord diagramu. Jeden súbor (polozky.csv) obsahuje jednotlivé položky matice (obce, prípadne ostatné atribúty sledovanej dochádzky). Druhý súbor obsahuje údaje matice a výsledný skript ho spracováva vo formáte *.json (matrix.json). Vždy ide o štvorcovú maticu, ktorej hodnoty sa líšia v kontexte toho či existuje alebo neexistuje vzt'ah medzi sledovanými entitami. Podoba oboch vstupných súborov pre diagram so vzájomným vzt’ahom medzi entitami je $v$ tab. 3 . V nej vidíme vidíme, že tvorba dvoch rozdielnych chord diagramov znázorňujúcich dochádzku, resp. odchádzku za prácou je výsledkom jednoduchého procesu transponovania vstupnej matice. V̌setky ostatné nastavenia ostanú nezmenené a získame dva rozdielne diagramy, ktoré sa odlišujú šírkou bázy konkrétnej mestskej časti, kedy v prvom prípade táto zobrazuje celkový počet odchádzajúcich a druhá celkový počet dochádzajúcich v danej mestskej časti. Hrúbka pruhov spájajúcich jednotlivé obce má pri jej báze rôznu šírku. Táto nám vyjadruje počet dochádzajúcich v oboch smeroch. Rovnako tak na diagramoch vidíme aj sumárne počty dochádzajúcich/odchádzajúcich za jednotlivé mestské časti Bratislavy (obr. 12). 
Tab. 3. Príklad zápisu vstupných súborov

\begin{tabular}{|c|}
\hline Súbor: polozky.csv \\
\hline $\begin{array}{l}\text { name, color } \\
\text { Bratislava-Staré Mesto,\#bdbdbd } \\
\text { Bratislava-Podunajské Biskupice, \#e5f5e0 } \\
\text { Bratislava-Ružinov,\#ald99b } \\
\text { Bratislava-Vrakuňa,\#3la354 } \\
\text { Bratislava-Nové Mesto,\#efedf5 } \\
\text { Bratislava-Rača,\#bcbddc } \\
\text { Bratislava-Vajnory,\#756bb1 } \\
\text { Bratislava-Devín,\#fee5d9 } \\
\text { Bratislava-Devínska Nová Ves, \#fcbba1 } \\
\text { Bratislava-Dúbravka,\#fc9272 } \\
\text { Bratislava-Karlova Ves,\#fb6a4a } \\
\text { Bratislava-Lamač,\#de2d26 } \\
\text { Bratislava-Záhorská Bystrica,\#a50f15 } \\
\text { Bratislava-Cunovo,\#ffffd4 } \\
\text { Bratislava-Jarovce,\#fed98e } \\
\text { Bratislava-Petržalka,\#fe9929 } \\
\text { Bratislava-Rusovce,\#cc4c02 }\end{array}$ \\
\hline Súbor: matrix.json (odchádzka za prácou do jednotlivých mestských častí) \\
\hline $\begin{array}{l}{[[0,106,2940,158,1395,238,32,9,103,145,332,46,28,0,0,770,0],} \\
{[2549,0,1650,128,531,116,37,0,59,55,86,16,0,0,0,390,0],} \\
{[7875,538,0,140,1929,414,103,14,155,230,427,72,33,0,0,1370,16],} \\
{[2154,345,1412,0,501,160,40,0,45,55,103,24,0,0,0,373,0],} \\
{[1934,97,1666,61,0,297,57,22,105,157,305,87,70,13,9,3221,42],} \\
{[885,33,803,36,868,0,109,19,78,61,147,45,19,0,0,2124,27],} \\
{[159,10,223,9,184,89,0,0,15,10,19,0,0,0,0,606,12],} \\
{[77,0,52,0,66,17,0,0,19,16,24,0,0,0,0,28,0],} \\
{[798,37,1032,83,1346,272,67,29,0,287,301,85,23,0,0,357,0],} \\
{[1876,75,1930,112,2384,513,145,26,482,0,640,172,50,0,0,756,0],} \\
{[1979,75,2111,139,2506,444,115,20,305,371,0,84,24,0,0,742,0],} \\
{[360,0,436,33,497,98,25,0,77,102,120,0,18,0,0,147,0],} \\
{[181,0,184,25,281,56,0,0,43,55,57,22,0,0,0,70,0],} \\
{[79,0,50,0,29,18,0,0,10,0,16,0,0,0,0,67,23],} \\
{[53,0,44,0,76,27,0,0,38,24,36,13,0,0,0,105,17],} \\
{[7110,377,6762,252,5300,2280,787,213,1720,1747,3154,795,286,90,116,0,66],} \\
[140,6,124,9,114,62,18,0,67,51,88,20,0,0,18,202,0]]\end{array}$ \\
\hline $\begin{array}{l}\text { Súbor: matrix.json (dochádzka za prácou do jednotlivých mestských častí - transpono- } \\
\text { vaná matica) }\end{array}$ \\
\hline $\begin{array}{l}{[[0,2549,7875,2154,1934,885,159,77,798,1876,1979,360,181,79,53,7110,140],} \\
{[106,0,538,345,97,33,10,0,37,75,75,0,0,0,0,377,6],} \\
{[2940,1650,0,1412,1666,803,223,52,1032,1930,2111,436,184,50,44,6762,124],} \\
{[158,128,140,0,61,36,9,0,83,112,139,33,25,0,0,252,9],} \\
{[1395,531,1929,501,0,868,184,66,1346,2384,2506,497,281,29,76,5300,114],} \\
{[238,116,414,160,297,0,89,17,272,513,444,98,56,18,27,2280,62],} \\
{[32,37,103,40,57,109,0,0,67,145,115,25,0,0,0,787,18],} \\
{[9,0,14,0,22,19,0,0,29,26,20,0,0,0,0,213,0],} \\
{[103,59,155,45,105,78,15,19,0,482,305,77,43,10,38,1720,67],} \\
{[145,55,230,55,157,61,10,16,287,0,371,102,55,0,24,1747,51],} \\
{[332,86,427,103,305,147,19,24,301,640,0,120,57,16,36,3154,88],} \\
{[46,16,72,24,87,45,0,0,85,172,84,0,22,0,13,795,20],} \\
{[28,0,33,0,70,19,0,0,23,50,24,18,0,0,0,286,0],} \\
{[0,0,0,0,13,0,0,0,0,0,0,0,0,0,0,90,0],} \\
{[0,0,0,0,9,0,0,0,0,0,0,0,0,0,0,116,18],} \\
{[770,390,1370,373,3221,2124,606,28,357,756,742,147,70,67,105,0,202],} \\
[0,0,16,0,42,27,12,0,0,0,0,0,0,23,17,66,0]]\end{array}$ \\
\hline
\end{tabular}

$V$ zápise dát sú zvýraznené hodnoty, ktoré sú zobrazené na obr. 12 

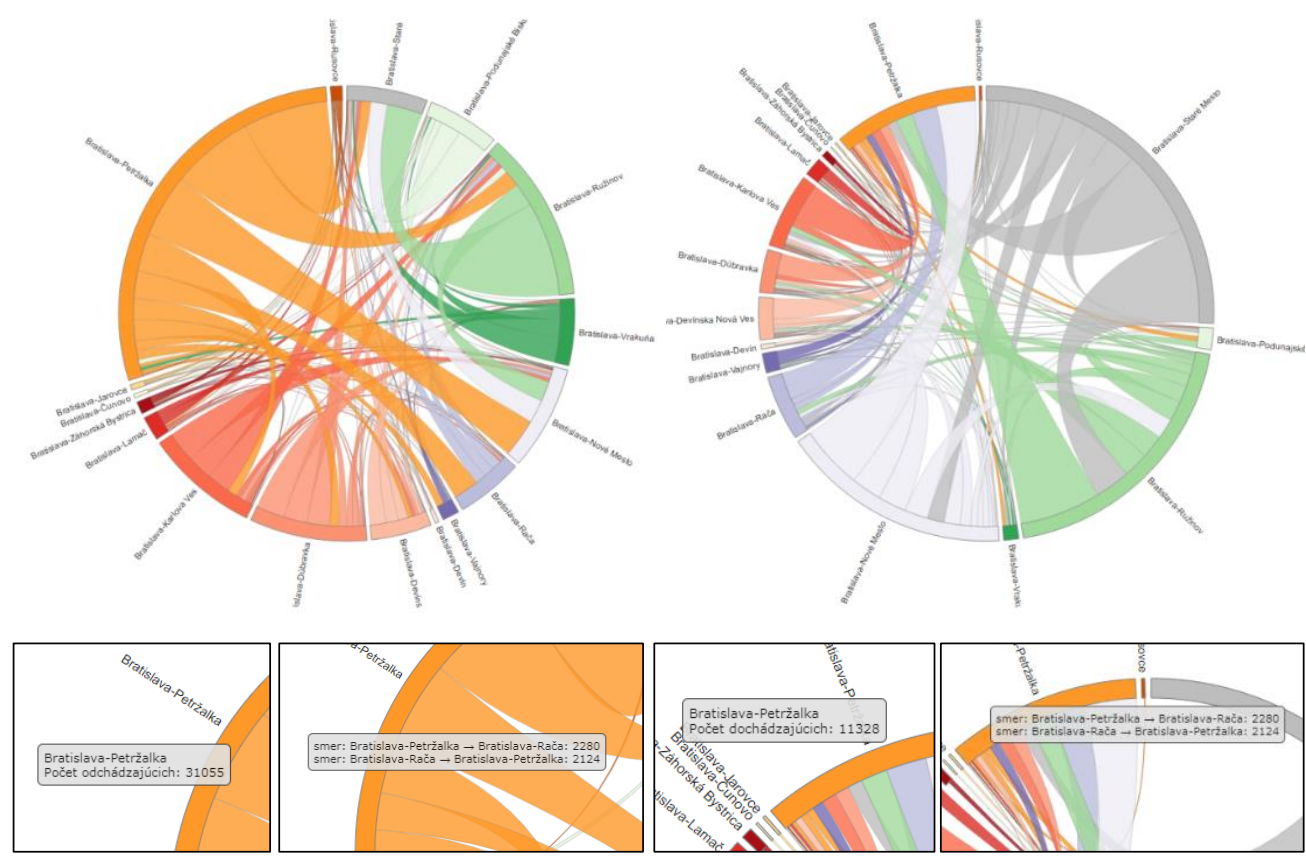

Obr. 12. Znázornenie odchádzky a dochádzky za prácou medzi Bratislavskými mestskými častami Interaktívnu verziu diagramu pre odchádzku uvádzame na stránke sobdtn.sk (Bačík 2019d). Interaktívnu verziu diagramu pre dochádzku uvádzame na stránke sobdtn.sk (Bačík 2019e).

Výpis príslušných hodnôt, ktoré sa zobrazujú na diagrame po prechode myšou na jednotlivé elementy (báza entity - groupTip, alebo príslušný pruh spájajúci dve entity - chordTip) je realizovaný zápisom vstupných dát v JavaScripte:

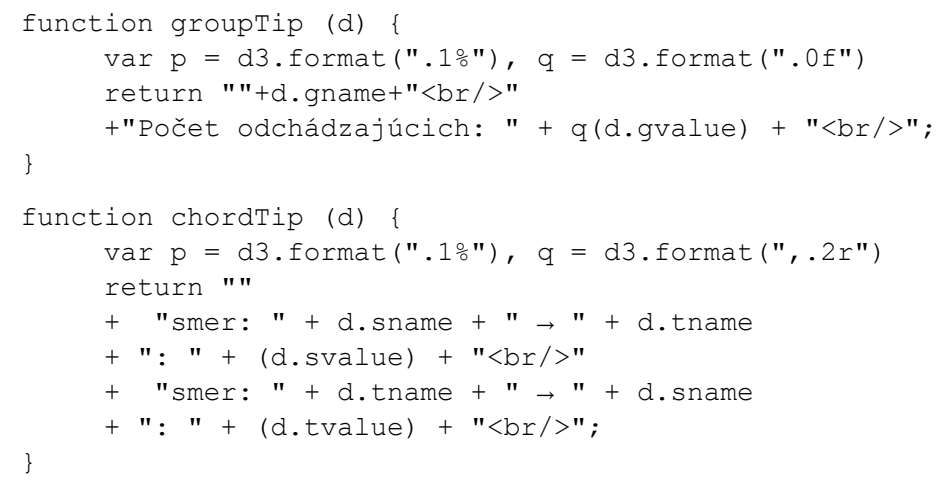

V prípade diagramov, bez vzájomnej súvzt’ažnosti je štruktúra vstupných súborov podobná, avšak pri súbore polozky.csv sú na konci doplnené d’alšie sledované atribúty (napr. dochádzka do práce, dochádzka do školy, odchádzka do práce a odchádzka do školy). Maticu potom tvorí okrem údajov pre jednotlivé obce (tieto sú nulové) aj doplnenie o d’alšie sledované hodnoty. Schéma takejto matice a výsledný chord diagram vidíme na obr. 13.

Výhodou takto vytvorených dynamických chord diagramov je priama interakcia s reálnymi dátami a vstupnými entitami, ktoré sú v tabul'kovej podobe ukryté. Rovnako tak atraktívne kruhové usporiadanie je výhodou oproti iným bežne používaným grafickým vyjadreniam, na kto- 
rých limity sme poukázali v časti „Cirkulárna vizualizácia“ nášho príspevku. Ako už bolo povedané, pri statickom vyjadrení chord diagramov treba čitatel'om ukázat' vhodný spôsob jeho interpretácie, resp. zacielit' jeho pozornost' na kl'účové dáta, ktoré mu chceme komunikovat' (týka sa to predovšetkým vel'kého množstva dát). Pri dynamickom vyjadrení je možné identifikovat' aj dáta s najnižšími hodnotami. Aj z týchto dôvodov sa chord diagramy v súčasnosti úspešne etablovali ako plnohodnotný grafický prvok pri tvorbe podobne orientovaných štatistických dát.

\begin{tabular}{|c|c|c|c|c|c|c|c|c|c|c|c|c|c|}
\hline & & 1 & 2 & 3 & 4 & 5 & & 87 & 88 & 89 & 90 & 91 & 92 \\
\hline & & 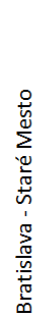 & 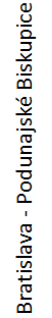 & 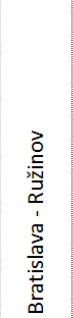 & 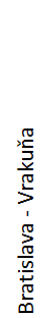 & 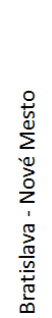 & 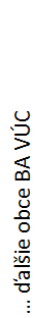 & 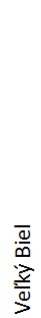 & $\overrightarrow{\underline{y}}$ & 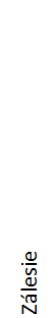 & $\begin{array}{l}\frac{\mathscr{D}}{0} \\
\frac{\pi}{\frac{\pi}{0}} \\
\frac{\pi}{N}\end{array}$ & 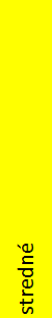 & 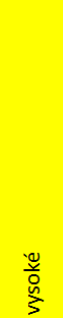 \\
\hline 1 & Bratislava - Staré Mesto & 0 & 0 & 0 & 0 & 0 & 0 & 0 & 0 & 0 & 393 & 508 & 779 \\
\hline 2 & Bratislava - Podunajské Biskupice & 0 & 0 & 0 & 0 & 0 & 0 & 0 & 0 & 0 & 375 & 375 & 376 \\
\hline 3 & Bratislava - Ružinov & 0 & 0 & 0 & 0 & 0 & 0 & 0 & 0 & 0 & 710 & 884 & 1637 \\
\hline 4 & Bratislava - Vrakuňa & 0 & 0 & 0 & 0 & 0 & 0 & 0 & 0 & 0 & 337 & 413 & 521 \\
\hline \multirow[t]{2}{*}{5} & Bratislava - Nové Mesto & 0 & 0 & 0 & 0 & 0 & 0 & 0 & 0 & 0 & 547 & 610 & 888 \\
\hline & ... d'alšie obce BA VÚc & 0 & 0 & 0 & 0 & 0 & 0 & 0 & 0 & 0 & $\mathrm{n}$ & $\mathrm{n}$ & $\mathrm{n}$ \\
\hline 87 & Vel'ký Biel & 0 & 0 & 0 & 0 & 0 & 0 & 0 & 0 & 0 & 61 & 69 & 48 \\
\hline 88 & Vlky & 0 & 0 & 0 & 0 & 0 & 0 & 0 & 0 & 0 & 34 & 25 & 15 \\
\hline 89 & Zálesie & 0 & 0 & 0 & 0 & 0 & 0 & 0 & 0 & 0 & 102 & 46 & 44 \\
\hline 90 & základné & 393 & 375 & 710 & 337 & 547 & $\mathrm{n}$ & 61 & 34 & 102 & 0 & 0 & 0 \\
\hline 91 & stredné & 508 & 375 & 884 & 413 & 610 & $n$ & 69 & 25 & 46 & 0 & 0 & 0 \\
\hline 92 & vysoké & 779 & 376 & 1637 & 521 & 888 & $\mathrm{n}$ & 48 & 15 & 44 & 0 & 0 & 0 \\
\hline
\end{tabular}
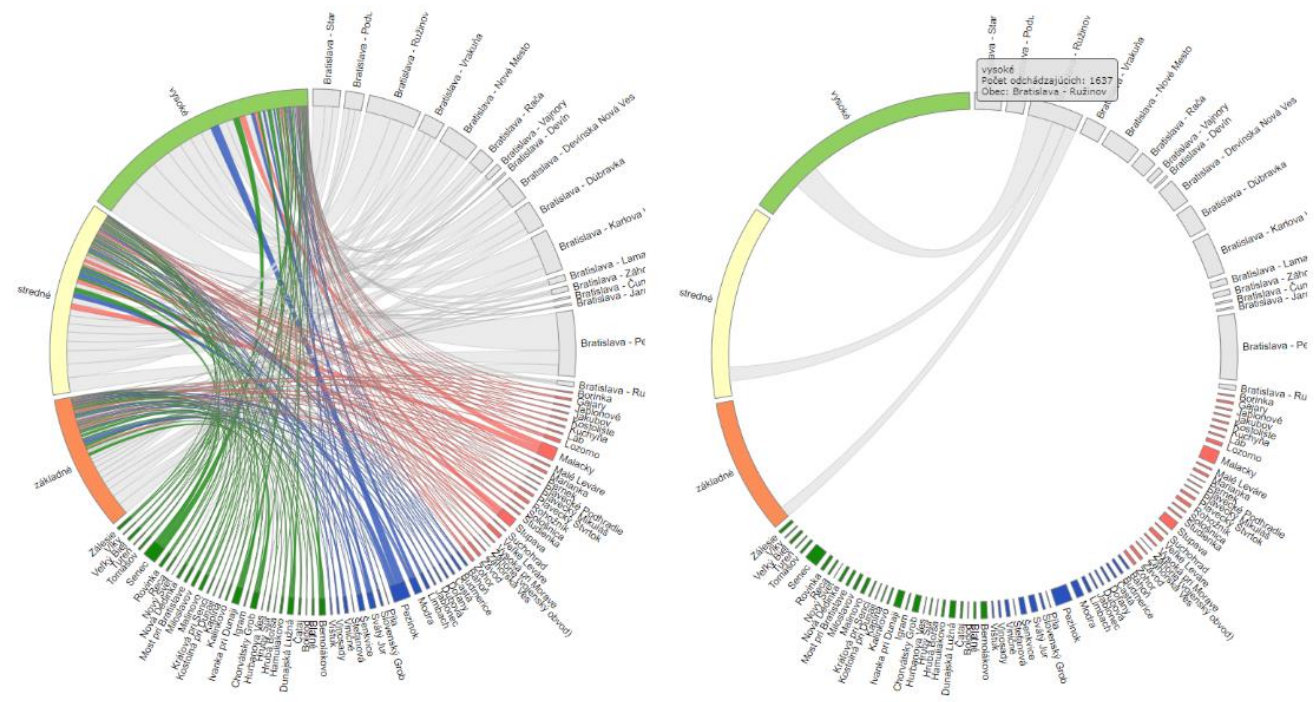

Obr. 13. Schéma matice a výsledný diagram pre diagramy „,bez vzájomného vzt’ahu medzi entitami “

Interaktívnu verziu diagramu uvádzame na stránke sobdtn.sk (Bačik 2019f). 


\section{Záver}

Ciel'om predloženého príspevku bolo poukázat' na možnosti zobrazenia dochádzkových dát pomocou cirkulárnej vizualizácie so zameraním na využitie tzv. chord diagramov. Impulzom pre napísanie nášho príspevku bola snaha o efektívne a atraktívne zobrazenie takýchto dát, $\mathrm{s}$ ktorými sa v geografickej, resp. demografickej praxi stretávame pomerne často. Efektívny spôsob vizualizácie umožní čitatel'om získat' špecifický pohl'ad na dáta a charakteristiky, ktoré sú v bežnej tabul'kovej podobe skryté. Inšpiráciou pre napísanie predloženého príspevku boli práce demografov (Abel, Sander 2014, Abel, Cohen 2019, Abel, Heo 2018), ktorí aplikovali túto formu grafického vyjadrenia na svetové migračné dáta. Práve takto orientované dáta, pri ktorých možno hovorit' o zdrojových a ciel'ových regiónoch, sú vel'mi vhodným príkladom takéhoto využitia.

Cirkulárna vizualizácia sa stala pomerne dominantnou v ostatných rokoch. Samotné dôvody sú dobre zachytené v príspevku Lima (2017), ktorý na základe dostupných štúdií poukazuje na prirodzenú preferenciu l'udí vnímat' okrúhle tvary ako pozitívny vnem zakorenený v l'udských organizmoch od narodenia. Popularita takéhoto grafického vyjadrenia je zrejmá aj s jej implementáciou vo viacerých štandardne používaných vizualizačných nástrojoch (napr. amCharts, Tableau, R, ZingChart, Highcharts, D3, Circos, atd'.). V našom príspevku sme použili nástroj Circos na tvorbu neinteraktívnych chord diagramov, v prípade interaktívnych chord diagramov sme využili knižnicu D3, s ktorej využitím máme praktické skúsenosti aj z minulosti. Diagramy vytvorené pomocou týchto nástrojov možno rozdelit' do dvoch základných skupín - interaktívne (D3) a bez interaktivity (Circos). V oboch prípadoch však ide o atraktívne kruhové usporiadanie sledovaných entít ( $\mathrm{v}$ našom prípade obce Bratislavského VÚC) a vzájomných vzt'ahov medzi nimi (dochádzkové dáta). Chord diagramy bez interaktivity sú vhodným nástrojom pri tvorbe prezentačných techník (postery, infografiky), pri ktorých chceme zaujat' čitatel'a už na prvý pohl'ad. Za istú nevýhodu môžeme považovat' relatívnu komplikovanost' čitatel'nosti týchto výstupov pre čitatel'ov, ktorí ešte nemajú s takýmito výstupmi bližšiu skúsenost'. Preto je vždy vhodné doložit’ ako súčast' diagramu aj základný „,návod““ ako postupovat' pri jeho čítaní. Dalšou nevýhodou môže byt' znížená prehl'adnost' čitatel'nosti v prípade vel'kého množstva vstupných dát. V takýchto prípadoch je však možné tieto diagramy upravit' tak, aby sme čitatel'ovu pozornost' zamerali na tie dáta, ktoré sú vzhl'adom na výsledky nášho výskumu relevantné. Obe tieto nevýhody eliminuje tvorba interaktívnych chord diagramov. V týchto prípadoch je možné odčítanie aj tých najmenších hodnôt $\mathrm{z}$ diagramu, ktoré sú v statickej podobe viac-menej skryté. Samotná interaktivita je limitovaná znalost’ami skriptovacích jazykov, ktorých jednotlivé techniky používajú tvorcovia výslednej prezentácie. Online chord diagramy pokrývajú spektrum od statických, až po dynamické animácie zachytávajúce dlhé časové obdobia (Abel, Sander 2014, Abel, Cohen 2019).

Dochádzkové dáta sú vzhl'adom na svoj charakter vel'mi vhodné na aplikovanie takejto vizuálnej formy. Tu sme znázornili jednak vzájomné dochádzkové väzby medzi sledovanými regiónmi, ako aj d’alšie dochádzkové atribúty, ktoré sú dostupné zo vstupných datasetov. $\mathrm{V}$ prípade migračných dát je možné aj zachytenie vnútroregionálnej migrácie (v takomto prípade by na diagonále vstupnej matice neboli nulové hodnoty, ale reálne hodnoty vnútroregionálnej migrácie). Vychádzajúc z konceptu popularity kruhového usporiadania entít a väzieb medzi nimi, je možné chord diagram použit' pri vizualizácii akýchkol'vek dát. Ako príklad možno uviest' aj aplikovanie chord diagramov na znázornenie výsledkov vzájomných zápasov medzi športovými tímami (športovcami) ${ }^{2}$. Aj tu ide o obojsmernú interakciu a takto znázornené vzájomné súperenie môže byt' obohatením športových štatistík.

Chord diagramy sú pomerne novým, avšak už pevne etablovaným grafickým prvkom pri vizualizácii dát. Ich využitie je vel'mi rôznorodé a užívatel'sky vysoko atraktívne, čo je predpokladom ich d'alšieho systematického využívania pri tvorbe rozličných printových a predovšetkým online interaktívnych aplikácií zameraných práve na vizualizáciu dát.

\footnotetext{
2 Pre zaujímavost' sme spracovali vzájomné zápasy medzi všetkými hráčmi tenisového rebrička ATP, ktorí boli aspoň 1 týždeň svetovou jednotkou. Výsledky sú dostupné na stránke: www.sodbtn.sk/atp/tenis.pdf (statická verzia), alebo www.sodbtn.sk/atp (interaktívna verzia)
} 


\section{Literatúra}

ABEL, G. J., COHEN, J. E. 2019: Bilateral international migration flow estimates for 200 countries. Sci Data, 6(82), 1-13. DOI: https://doi.org/10.1038/s41597-019-0089-3.

ABEL G. J., HEO, N. 2018: Changing internal migration flows patterns in South Korea. Regional Studies, Regional Science, 5(1), 78-80. DOI: https://doi.org/10.1080/21681376. 2018.1431149.

ABEL, G. J., SANDER, N. 2014: Quantifying global international migration flows. Science, 343(6178), 1520-1522. DOI: https://doi.org/10.1126/science.1248676.

ALI, S. M., GUPTA, N., NAYAK , G. K., LENKA, R. R. 2016: Big data visualization: Tools and challenges. In Niranjan, S. K., Manjunatha Aradhya, V. N. eds. 2016 2nd International Conference on Contemporary Computing and Informatics (IC3I). India, Noida (IEEE), 2016, pp. 656-660. DOI: https://doi.org/10.1109/IC3I.2016.7918044.

ANDERSEN, J. E., FUJI, H., MANABE, M., PENNER, R. C., SULKOWSKI, P. 2016: Enumeration of chord diagrams via topological recursion and quantum curve techniques. Mathematical Physics. arXiv preprint arXiv:1612.05839.

BAČÍK, V. 2019a: Ako čítat' chord diagram. SOBDTN.sk. Dostupné na: http://www.sodbtn.sk/dochadzka_ba/ako_citat_chord.png.

BAČ́́K, V. 2019b: Statické chord diagramy. SOBDTN.sk. Dostupné na: http://sodbtn.sk/dochadzka_ba/staticke_chord_diagramy.pdf.

BAČÍK, V. 2019c: Vizualizácia dochádzky a odchádzky v podobe chord-diagramov. SOBDTN.sk. Dostupné na: http://www.sodbtn.sk/dochadzka_ba/.

BAČÍK, V. 2019d: Odchádzajúci v mestských častiach BA medzi sebou. SOBDTN.sk. Dostupné na: http://sodbtn.sk/dochadzka_ba/chord18.php.

BAČÍK, V. 2019e: Dochádzajúci v mestských častiach BA medzi sebou. SOBDTN.sk. Dostupné na: http://sodbtn.sk/dochadzka_ba/chord19.php.

BAČÍK, V. 2019f: Odchádzka z obcí BA kraja do škôl. SOBDTN.sk. Dostupné na: http://www.sodbtn.sk/dochadzka_ba/chord6.php.

BOSTOCK, M., OGIEVETSKY, V., HEER, J. 2011: $\mathrm{D}^{3}$ data-driven documents. IEEE transactions on visualization and computer graphics, 17(12), 2301-2309. DOI: https://doi.org/10.1109/TVCG.2011.185.

BYLINSKII, Z., KIM, N. W., O'DONOVAN, P. et al. 2017: Learning visual importance for graphic designs and data visualizations. Proceedings of the 30th Annual ACM Symposium on User Interface Software and Technology, 57-69. DOI: https://doi.org/10.1145/ 3126594.3126653.

GRACE, S. 2018: Lessons from 'losses from the Russian campaign'. The Art of Consequences. Retrieved from: https://edspace.american.edu/visualwar/minard/.

FLAJOLET, P., NOY, M. 2000: Analytic combinatorics of chord diagrams. In Krob, D., Mikhalev A. A., Mikhalev A. V. Formal Power Series and Algebraic Combinatorics. Berlin (Springer, Berlin, Heidelberg), pp. 191-201. DOI: https://doi.org/10.1007/978-3-66204166-6_17.

FRIENDLY, M. 2008: A brief history of data visualization. In Chen, Ch., Härdle, W., Unwin, A. eds. Handbook of data visualization. Berlin (Springer, Berlin, Heidelberg), pp. 15-56.

HOLTEN, D. 2006: Hierarchical edge bundles: Visualization of adjacency relations in hierarchical data. IEEE Transactions on visualization and computer graphics, 12(5), 741-748, DOI: https://doi.org/10.1109/tvcg.2006.147.

KIRK, A. 2012: Data Visualization: a successful design process. Birmingham (Packt Publishing Ltd).

KRZYWINSKI, M., SCHEIN, J., BIROL, I. et al. 2009: Circos: an information aesthetic for comparative genomics. Genome research, 19(9), 1639-1645. Retrieved from: http://mkweb.bcgsc.ca/tableviewer/. DOI: https://doi.org/10.1101/gr.092759.109. 
LIMA, M. 2017: The book of circles: Visualizing spheres of knowledge. New York (Princeton Architectural Press).

PHAN, D., XIAO, L., YEH, R., HANRAHAN, P. 2005: Flow map layout. IEEE Symposium on Information Visualization, 219-224. DOI: https://doi.org/10.1109/INFVIS.2005.1532150.

PURSEL, B. 2005: Information, People, and Technology. State College (The Pennsylvania State University). Retrieved from: https://psu.pb.unizin.org/ist110/.

SANDER, N., ABEL, G. J., BAUER, R., SCHMIDT, J. 2014: Visualising migration flow data with circular plots. In Goujon, A., Streissnig, E. eds. Working Papers. Vienna (Vienna Institute of Demography).

STOIMENOW, A. 2000: On the number of chord diagrams. Discrete Mathematics, 218(1-3), 209-233. DOI: https://doi.org/10.1016/S0012-365X(99)00347-7.

TUFTE, E. R. 2001: The visual display of quantitative information (Vol. 2). Cheshire, CT: Graphics press.

WANG, C., YU, H., MA, K. L. 2008: Importance-driven time-varying data visualization. IEEE Transactions on Visualization and Computer Graphics, 14(6), 1547-1554. DOI: https://doi.org/10.1109/TVCG.2008.140.

ZHOU, H., XU, P., YUAN, X., QU, H. 2013: Edge bundling in information visualization. Tsinghua Science and Technology, 18(2), 145-156. DOI: https://doi.org/10.1109/TST. 2013.6509098.

Pod'akovanie: Príspevok vznikol vd'aka projektu APVV-17-0079 „Analýza a prognóza demografického vývoja Slovenskej republiky v horizonte 2080: identifikácia a modelovanie dopadov na sociálno-ekonomickú sféru v rozličných priestorových mierkach“.

\author{
Adresy autorov \\ Mgr. Vladimír Bačík, PhD. \\ Katedra ekonomickej a sociálnej geografie, demografie a územného rozvoja \\ Prírodovedecká fakulta, Univerzita Komenského v Bratislave \\ Ilkovičova 6, Mlynská dolina, \\ 84215 Bratislava \\ Slovensko \\ vladimir.bacik@uniba.sk
}

Mgr. Dominika Chvosteková

Kristy Bendovej 4,

84102 Bratislava

Slovensko

dominika.chvostekova@gmail.com 